Fate of Nonindigenous, EndosporeForming Bacteria in Soils Strategies for Laboratory and Field Investigations

Charles M. Reynolds, Karen L. Foley, David B. Ringelberg, and Lawrence B. Perry

US Army Corps of Engineers ${ }_{\circledast}$ Engineer Research and Development Center
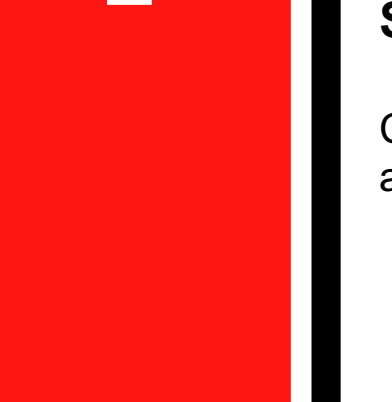

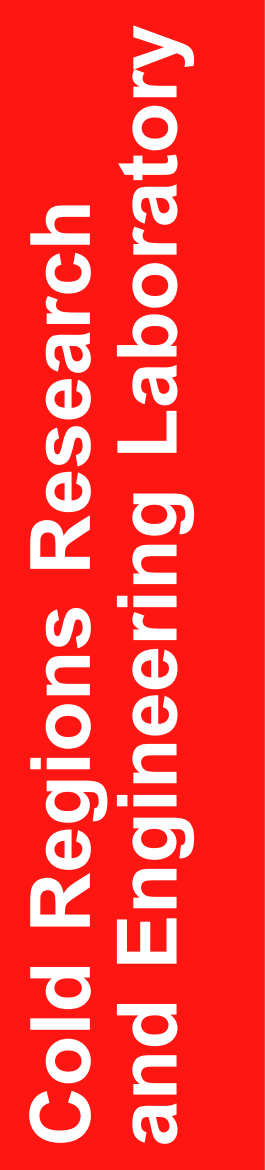


ERDC/CRREL TR-03-23

November 2003

\section{Fate of Nonindigenous, Endospore- Forming Bacteria in Soils \\ Strategies for Laboratory and Field Investigations}

Charles M. Reynolds, Karen L. Foley, David B. Ringelberg, and Lawrence B. Perry

Approved for public release; distribution is unlimited.

Prepared for OFFICE OF THE CHIEF OF ENGINEERS 


\section{ABSTRACT}

Persistence of nonindigenous microorganisms released onto soils or into natural environments can have a significant impact on Department of Defense (DoD) operations. An understanding of competition among various microbial communities is necessary to accurately predict the types of microorganisms that will flourish as well as those that will wane under differing environmental scenarios. In the past, soil microbiology was altered with brute-force techniques such as the saturation of a soil with a decontamination agent. An approach that is more feasible for large areas is to alter soil conditions to promote the desired microbial status or to effectively predict their fate in field conditions. Ultimately, the ability to accurately predict the occurrence of a dominant microbial community will be useful both for predicting the fate of pathogens in the environment and for fostering success in the bioremediation of soils and sediments.

Bacillus globigii (BG) was selected to investigate the persistence and fate of nonindigenous bacteria released onto soils. We were able to differentiate BG from indigenous bacteria by combining culturing techniques with lipid-based validation. Enrichment on agar plates produced bright orange BG colonies that were clearly distinct from native microorganisms. These data suggest that there is either an initial loss in viability or an inability to recover $10-15 \%$ of the BG soon after inoculation onto the soil.

DISCLAIMER: The contents of this report are not to be used for advertising, publication, or promotional purposes. Citation of trade names does not constitute an official endorsement or approval of the use of such commercial products. All product names and trademarks cited are the property of their respective owners. The findings of this report are not to be construed as an official Department of the Army position unless so designated by other authorized documents. 


\section{CONTENTS}

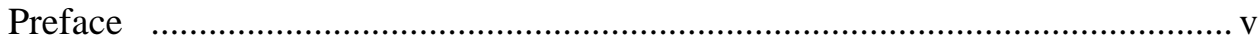

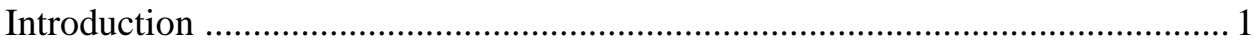

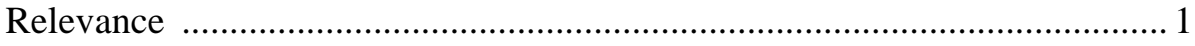

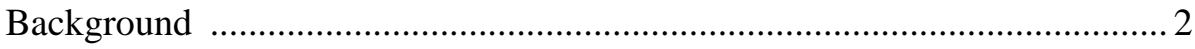

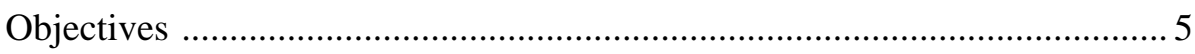

Objective 1: Differentiating nonindigenous bacteria

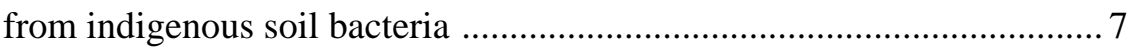

Materials and methods .......................................................................... 7

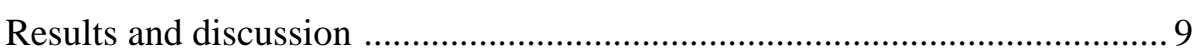

Objective 2: Differentiating vegetative Bacillus cells from endospores ............ 10

Materials and methods ............................................................................... 11

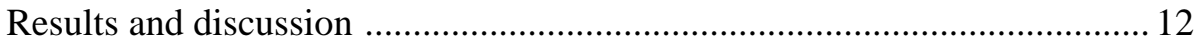

Objective 3: Reproducing endospore and vegetative cell cultures .....................13

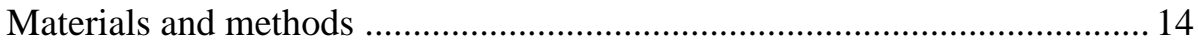

Results and discussion ......................................................................... 16

Objective 4: Recovery of Bacillus from soil .................................................... 20

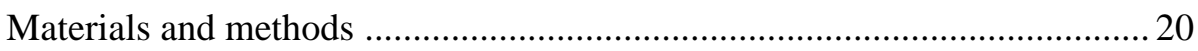

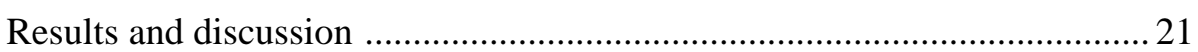

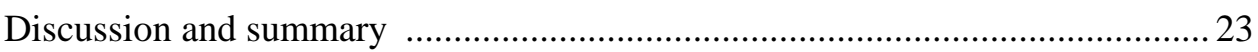

Impediment to decontaminating complex surfaces such as soils .................23

Alternative strategy for decontaminating soils ............................................ 24

Using BG as a model organism ................................................................ 25

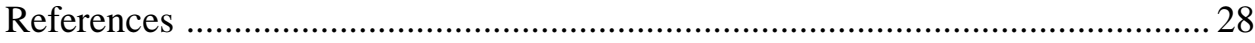

Appendix A. Procedures for media preparation, soil dilutions series, plating, incubation, counting, and cleanup ......................................................... 33

Appendix B: Schaeffer-Fulton Method for endospore staining .......................... 37

Appendix C: Protocol for sampling Nephelo flasks ........................................... 38 


\section{ILLUSTRATIONS}

Figure 1. Representative plates of Bacillus globigii (BG), native soil

bacteria, and both native soil bacteria and BG from BG-inoculated

soil grown on full-strength TSA medium

Figure 2. Effect of different treatments used to kill vegetative cells

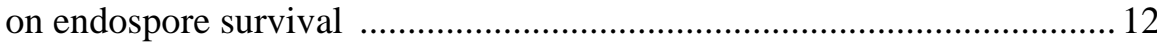

Figure 3. Turbidity-derived growth curves of BG grown from endospores using a range of carbon sources for BG growth 15

Figure 4. Turbidity-measured growth curves of BG grown from endospores in $0.1 \times$ TSB

Figure 5. Relationship between formazin turbidity units obtained from Nephelo flasks and cell density obtained from plate counts 17

Figure 6. Formazin turbidity units and numbers of colony-forming units for vegetative cells and endospores at each change in BG growth cycle .......18

Figure 7. Recovery of viable BG from soil following endospore addition and

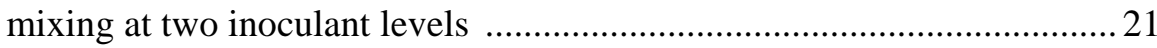

\section{TABLE}

Table 1. Selected physiochemical properties of Alaskan field soil used in these studies 8 


\section{PREFACE}

This report was prepared by Charles M. Reynolds, Research Physical Scientist; Karen L. Foley, Physical Science Technician; David B. Ringelberg, Research Microbiologist; and Lawrence B. Perry, Lead Physical Scientist Technician, of the U.S. Army Corps of Engineers Engineer Research and Development Center (ERDC), Cold Regions Research and Engineering Laboratory in Hanover, New Hampshire.

This research was supported by the ERDC Military Engineering Research Program, Project AT24-FG-003, Pathogen Persistence in Soils Subject to Freeze-Thaw Cycles, Focus Area: Cold Regions Terrain Physical, Chemical, and Biological Processes. The authors appreciate the insightful review comments of Gary Koh and Dr. Kathleen White and the assistance of Susan Hardy in the preparation.

The Commander and Executive Director of ERDC is COL James R. Rowan, EN. The Director is Dr. James R. Houston. 


\title{
Fate of Nonindigenous, Endospore-Forming Bacteria in Soils \\ Strategies for Laboratory and Field Investigations
}

\author{
CHARLES M. REYNOLDS, KAREN L. FOLEY, \\ DAVID B. RINGELBERG, AND LAWRENCE B. PERRY
}

\section{INTRODUCTION}

\section{Relevance}

Understanding the persistence of nonindigenous microorganisms released onto soils and into other natural environments is important to the United States and the Department of Defense (DoD). The transformation of the Army is leading to changes in operations, training, and subsequent needs. This research precedes Army-relevant applications requiring knowledge of microbial fate in natural systems, including the following:

1. Our ability to address asymmetrical warfare, bioterrorism, and biowarfare depends in part on knowledge and prediction of the persistence and fate of microorganisms in natural systems; this ability is increasingly important for the nation, the Department of Defense, and the Army. Predicting the persistence of pathogens that are nonindigenous to a soil and that have been intentionally released-including scenarios where pathogens are released into the atmosphere and subsequently deposited onto soil-is increasingly important to U.S. interests and requires an understanding of pathogen interactions in soil systems. Techniques gained from understanding soil systems may have greater application for decontaminating complex surfaces found in structures-such as porous tiles, carpets, and dust-laden vents.

2. Bioremediating contaminants in soil by stimulating native microorganisms or introducing novel microorganisms can provide a low-cost, low-maintenance treatment system. This application includes situations where we are trying to promote the growth of a desirable microorganism or community of microorganisms. In some cases, bioaugmentation- 
altering the indigenous microbial population with bulk additions of a novel organism or consortium-may be beneficial. Understanding conditions that give the desired microorganism or consortium a competitive advantage after their release into a contaminated site is prerequisite to obtaining the desired results.

3. We need to be able to predict how changes in regional weather patterns or climate will affect Army-relevant operations. Changes in climate or regional weather patterns may subsequently cause changes in wetland acreage, changes in wetland conditions, changes in soil temperatures, or a combination of factors that can affect the growth and survival of pathogenic microorganisms. For planning and conducting both military and civilian operations, an ability to predict the effects of changing environmental conditions on pathogen fate will minimize human health risks.

4. Promoting die-off or reducing numbers of undesirable microorganisms associated with process materials and wastes, such as bio-solids or dredged material, can minimize health risks. Examples include pathogen reduction in dredged sediments placed into a confined treatment facility and treating wastewater using overland flow. In these systems the relative inability of nonindigenous microorganisms to compete with indigenous microorganisms in a foreign environment is exploited.

\section{Background}

The ubiquity of microorganisms in natural environments and their importance in governing biochemical processes in soil systems underscore the need to understand microbial interactions within the environment. An ability to predict the emergence of a dominant microbial community would prove useful for forecasting and altering pathogen fate and for fostering success in bioremediation. Past attempts to alter soil microbiology involved brute-force techniques, such as heavy doses of inoculants for bioaugmentation at remediation sites and applying soil sterilants for increasing pathogen die-off (Mierzejewski and Bartoszcze 1991, Small et al. 2001). Although these approaches can have a significant impact on soil microbiology, they are expensive, pose logistical problems, are usually incomplete, and are ephemeral, as the soil system often recovers towards its optimum pretreatment microbial status. A less aggressive and more lasting approach is to alter soil conditions to promote a desired microbial status. Survival of Bacillus anthracis in soil is known to vary with soil conditions and soil properties (Lindeque and Turnbull 1994, Dragun and Jenny 1995, Nicholson and Law 1999). It would be beneficial to use these underlying phenomena to manage the soils so that pathogen die-off is maximized. To do this, it is necessary to understand the effects of soil properties, competition among both indigenous 
and nonindigenous microbial communities, and soil environmental conditions. With an increased understanding of these interactions, predicting the groups of microorganisms that will flourish and those that will wane during different conditions is feasible, and strategies to favor desired outcomes can be devised.

The intent of the research described in this report was to evaluate and build on culture-based procedures for investigating the persistence and fate of nonindigenous bacteria added to soil as endospores. Endospore formation is not a common capability of bacteria, yet endospore-forming bacteria, such as Bacillus, are common in soils (Smalla et al. 2001). Endospores provide unique advantages in terms of handling, storage, and dissemination. Understanding linkages between soil conditions and endospore survival and fate has potential applications to Army-relevant issues including predicting the fate of biological agents, such as Bacillus anthracis, added to soil and modeling the dispersion and subsequent growth of bacteria having desirable degradative pathways, such as a Clostridia sp. that metabolize TNT (Adrian and Arnett 2001). Bacillus and Clostridia are both endospore-forming bacteria and also represent aerobic and anaerobic capabilities, respectively. This report targets aerobic systems and Bacillus.

\section{Pathogenic endospores}

The potential for using biological weapons of mass destruction (BWMD) is increasingly recognized as a major threat to U.S. personnel, both military and domestic (Atlas 1998, Busbee 1998, Osterholm 1998, Smith et al. 1998). Readiness against BWMD threats has been categorized into three elements: detection, protection, and decontamination (Busbee 1998, Moore 1998, Steinmetz et al. 1998, Wooten 1998). U.S. domestic readiness against BWMD threats follows a similar structure (Steinmetz et al. 1998). Decontamination is recognized as a major gap in our capabilities (Busbee 1998, Lynch 1998, Menetry and Coverstone 1998, Wooten 1998).

A likely BWMD candidate for use against the U.S. is anthrax (Bacillus anthracis). Bacillus anthracis produces endospores-microbial structures that withstand extreme environmental stresses such as cold, heat, radiation, acidity, toxic chemicals, and desiccation (Roberts and Hitchens 1969). In natural systems, bacterial endospore formation has evolved as a survival mechanism, primarily in the genera Bacillus and Clostridia, and is generally induced by poor growth conditions, such as nitrogen or carbon deficiency (Vinter 1969). Compared to the normal bacterial growth morphology - termed "vegetative" growth—endospores are remarkably difficult to kill. 
The most probable mechanism for BWMD use against military or domestic personnel is thought to be dispersion of endospores, which can infect personnel by both immediate and delayed exposure. Letters containing Bacillus anthracis endospores mailed in the U.S. in 2001 have dramatically illustrated the potential for using endospores of Bacillus anthracis as a dissemination technique. Endospores rapidly revegetate and multiply following inhalation. Delayed exposures, such as from inhaling endospores or endospore-laden dust, are potential threats. Although endospores dispersed onto soil can be killed by natural ultraviolet radiation (UV) (Gardner and Shama 1998), UV penetrates only minimally into soil surface irregularities and can be blocked by a fine dust layer. Endospores are resistant to most other environmental stresses, such as desiccation and starvation, and endospore formation is a survival strategy for some bacteria in soil. Consequently, viable, although not necessarily pathogenic, endospores are found in most soils (Smalla et al. 2001). Endospores of nonindigenous Bacillus deposited on soils have persisted for decades (Dragun and Jenny 1995, Mierzejewski and Bartoszcze 1991, Smith and Barry 1998). The decontamination of an endosporecontaminated installation would be exceedingly difficult due to the inherent survivability of bacterial endospores.

\section{Decontamination of soils}

The laboratory procedure for killing endospores requires moist heat at $130^{\circ} \mathrm{C}$ for 20 minutes (Perkins 1969). Plainly, this is not feasible on a field or installation scale. Structures and equipment, being non-porous, can be washed or fogged with an oxidant, thereby chemically inactivating endospores, although even this approach has limitations (Penna et al. 1999). Decontaminating soils is a greater challenge. Two current decontamination strategies for surface soils are (a) to rely on a "natural attenuation" approach based on UV light disinfection and the natural dilution of endospores spread over an area, or (b) to "disinfect" the soil using a strong oxidant such as bleach. For soils, disinfecting with a strong oxidant poses logistical problems, and there is evidence that this is ineffective (Small et al. 2001). The common occurrence of native endospores in soils suggests that relying on natural UV to kill endospores in soil would also be ineffective, and recent research supports this concept (Nicholson and Law 1999). In a severe test of UV inactivation, Bacillus endospores in a water suspension exposed to seven hours of direct sunlight on a concrete surface continued to show growth activity (Obeta 1996). Endospores in a dilute water suspension would receive significantly greater UV exposure than would endospores in soil. There is significant variability in endospore resistance to UV decomposition (Obeta 1996), and Bacillus endospores applied to soil have been recovered in a viable state well 
above background levels from two to over forty years after their dispersion (Mierzejewski and Bartoszcze 1991, Smith and Barry 1998).

Periodic changes in the soil environment, such as wet-dry cycles, freezethaw cycles, and burning, typically favor the growth of microorganisms because of the sudden release of carbon and nutrients. Yet nonindigenous microorganisms added to soil generally do not persist at high levels, most likely because of natural competition from indigenous microorganisms that are better adapted to the particular environment. Recent molecular techniques for estimating bacteria in soil have shown that when using traditional isolation and cultivation techniques, upon which most soil microbial data have been obtained, we can obtain growth from only approximately $1-10 \%$ of the bacteria in soil (Torsvik et al. 1990). In addition, long-term bacterial persistence in soils or other environments may be due to non-spore-forming bacteria entering into a viable but nongrowth state, variously described as "dormant," "quiescent," "ultramicrobacterial," "mimicell," "cryptically growing," or "resting” (Colwell and Grimes 2000). In many soils, a detectable but low level of some pathogenic organisms may occur, usually at a pseudo-steady-state density. These facts suggest that soils in temperate climates could eventually recover from a BWMD attack. However, there is little known about the rate of recovery, the types of actions that could be taken to hasten the recovery, or (conversely) the types of actions that may delay recovery. Addressing these knowledge gaps is important for both homeland defense and military operations.

\section{Hypothesis}

We hypothesize that the natural die-off of nonindigenous endospore-forming bacteria added to soils could be hastened by inducing their revegetation into a morphology that is most vulnerable while altering soil conditions to favor the growth and metabolism of indigenous microorganisms. To identify soil conditions that promote this, it is necessary to have the capability to

- Differentiate indigenous from nonindigenous bacteria in soil, and

- Differentiate endospores from vegetative cells for the nonindigenous bacteria added to soil.

\section{Objectives}

The purpose of the series of studies reported here was to test and build on existing culture-based procedures to be used in conducting studies on the persistence and fate of nonindigenous, endospore-forming bacteria added to soil. These capabilities are a prerequisite to developing an understanding of how soil 
processes, natural or artificially induced, can be used to attenuate nonindigenous pathogens in soil. Because these are complex biological systems, there is substantial inherent variability. Identifying treatment effects is often hindered by the variability in the system, and techniques that impose reproducible inputs to a soil system are needed. We identified four objectives to improve our ability to characterize the fate and persistence of endospores added to soil:

- Objective 1-Evaluate and modify existing techniques for differentiating nonindigenous Bacillus from indigenous bacteria in a soil.

- Objective 2-Reproducibly differentiate vegetative Bacillus cells from their endospores.

- Objective 3- Develop standard operating procedures to reproducibly generate Bacillus cultures that are predominantly endospore or predominantly vegetative cell. This was a prerequisite to accomplishing objective 4 .

- Objective 4- Determine the extent that nonindigenous Bacillus introduced onto soil could be recovered, both immediately following soil inoculation and after increasing incubation periods. This would allow us to document the fate of the introduced bacteria. 


\section{OBJECTIVE 1: DIFFERENTIATING NONINDIGENOUS BACTERIA FROM INDIGENOUS SOIL BACTERIA}

The population density of culturable bacteria in a surface soil is typically on the order of $10^{6}$ colony-forming units (CFUs) per gram of soil. Torsvik et al. (1990) used the heterogeneity of DNA extracted from soil to estimate that a gram of soil may contain approximately $10^{4}$ microbial species. Understanding the fate of nonindigenous bacteria added to soil requires an ability to differentiate the added bacteria from the native populations.

\section{Materials and methods}

For the non-indigenous bacteria, a Bacillus globigii (BG) endospore culture was obtained as a dry powder from the Dugway Proving Grounds. 'We refer to this culture, alternatively identified as Bacillus subtilis or Bacillus subtilis var. niger, as BG. This is the organism favored for use as a Bacillus anthracis surrogate in aerosol studies. ${ }^{\dagger}$

When grown on tryptic soy agar (TSA), specific Bacillus globigii (BG) colonies can appear orange. ${ }^{\dagger}$ We grew BG on TSA to select for and identify the characteristic orange colonies. Fatty acid methyl ester analysis (FAME) techniques were used to verify the genus and species of the selected colonies. In brief, FAME identification is based on the species-uniqueness of fatty-acid profiles for microorganisms grown in specific conditions on defined media. We used FAME procedures described by Sasser (1990) and Sasser and Wichman (1991), in which the fatty acid (FA) profile of an unknown is compared to the FA profile from a bacterial reference library (MIDI 1995). Using this approach, characterization to the genus and species level is typically possible. Isolates that cannot be identified using the standard FA library can be given an internal laboratory identifier and added to the library. In this way, unknown isolates that have fatty-acid profiles that are distinctively different from other known or unknown microorganisms can be differentiated. Similarities among FA profiles of known and unknown organisms can also be used to assign unknowns to specific functional or taxonomic groups.

For the indigenous soil bacteria, we obtained a viable Alaskan field soil with a total organic carbon content of $7.4 \%$, a total nitrogen content of $0.2 \%$, and

\footnotetext{
* BG endospores were provided by Dan Martin and Lloyd Larsen, Dugway Proving Grounds.

† Personal communication, Dan Martin, Dugway Proving Grounds.
} 
approximately $10^{7} \mathrm{CFU} / \mathrm{g}$ of soil, a relatively high number of culturable bacteria. The soil properties are provided in Table 1. Organisms were isolated following serial dilution of the soil by spread-plating the dilutions onto $0.1 \times$ TSA (Zuberer 1994). Procedures for media preparation, soil dilutions series, plating, incubation, counting, and cleanup are provided in Appendix A.

Bacterial colonies were also enriched from the soil and identified using the same system. BG was then mixed with the soil and plated on the enrichment agar (TSA) to verify that the BG colonies could be visually distinguished from the indigenous soil bacteria. We used the FAME procedure to identify selected colonies from enrichment plates of the Alaskan field soil and to confirm that the orange colonies grown on TSA from the Dugway inocula were BG.

\begin{tabular}{|c|c|c|}
\hline Analysis & Sample 1 & Sample 2 \\
\hline $\mathrm{pH}$ & 5.8 & 5.8 \\
\hline Texture & Silt loam & Silt loam \\
\hline Nitrogen & $0.2 \%$ & $0.3 \%$ \\
\hline Calcium, Mehlich 3 & 3177 ppm & 2985 ppm \\
\hline Magnesium, Mehlich 3 & 631 ppm & 620 ppm \\
\hline Potassium, Mehlich 3 & 87 ppm & 79 ppm \\
\hline Phosphorus, Mehlich 3 & 114 ppm & 125 ppm \\
\hline Lead, Mehlich 3 & $2 \mathrm{ppm}$ & $2 \mathrm{ppm}$ \\
\hline Organic matter & $7.4 \%$ & $7.4 \%$ \\
\hline Estimated $\mathrm{C} / \mathrm{N}$ ratio & 19.5 & 13 \\
\hline $\mathrm{NO}_{3}-\mathrm{N}$, Spurway & $1 \mathrm{ppm}$ & $1 \mathrm{ppm}$ \\
\hline $\mathrm{NH}_{4}-\mathrm{N}$, Spurway & $<3.2 \mathrm{ppm}$ & $4 \mathrm{ppm}$ \\
\hline
\end{tabular}




\section{Results and discussion}

Visual and FAME identification of Dugway BG

BG endospores obtained from Dugway Proving Grounds and enriched on both full strength and $0.1 \times$ TSA showed excellent growth, indicating that TSA was an appropriate medium for BG cultivation (Fig. 1a). The enriched BG colonies were distinctively orange with a darker orange center. FAME analysis identified the orange colonies as Bacillus subtilis var. niger (BG).

\section{Visual and FAME characterization of Alaskan soil bacteria}

Enrichment plates were prepared from the Alaskan soil in the same manner as for the Dugway BG. No orange colonies appeared on the plates following incubation (Fig. 1b). FAME analysis of selected colonies did not show any match to that obtained for the Dugway BG. These results suggested that the robust native population in the Alaskan soil could be readily differentiated from the introduced BG based on visual inspection alone.

\section{Visual confirmation of Dugway BG enrichment in Alaskan soil}

When we added BG inoculant to the Alaskan soil and then enriched the microorganisms on TSA, BG colonies appeared distinctively orange and were readily differentiated from the indigenous soil bacteria (Fig. 1c). These results, again confirmed with FAME analysis, demonstrated that BG could serve as a model endospore-forming, nonindigenous bacteria for determining the fate of an introduced pathogen in a natural or perturbed environment.

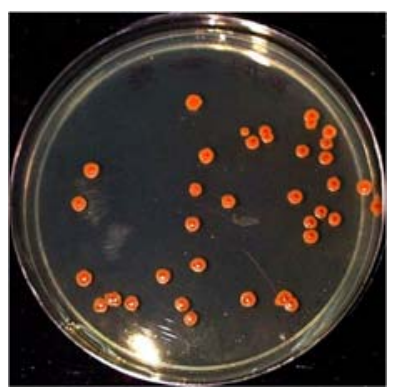

a

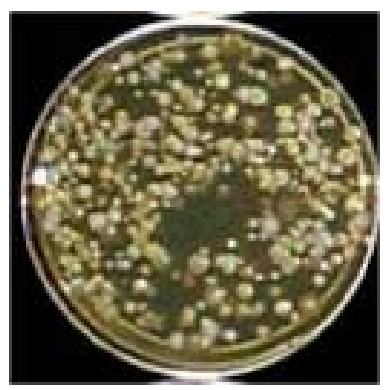

b

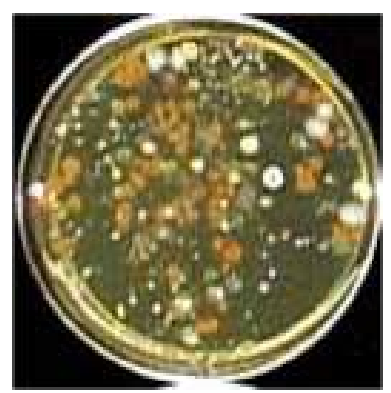

C

Figure 1. Representative plates of (a) Bacillus globigii (BG), (b) native soil bacteria, and (c) both native soil bacteria and BG from BG-inoculated soil grown on full-strength TSA medium. 


\section{OBJECTIVE 2: DIFFERENTIATING VEGETATIVE BACILLUS CELLS FROM ENDOSPORES}

After soils are serially diluted, plated on TSA, and incubated, both endospores and vegetative cells grow and produce colonies. Separating vegetative cells from endospores, therefore, must be done before the cells are plated. Our need was to develop a reliable method to reproducibly kill the vegetative cells but not the endospores in a sample.

Our purpose was not merely to isolate endospores from vegetative cells, which can be done by killing all the vegetative cells and a portion of the endospores, but to more quantitatively separate endospores and vegetative cells. We reasoned that there would be a range of acceptable time and temperature conditions that would reproducibly kill vegetative cells yet have a minimal impact on endospores.

Two methods described in the literature had potential application because they preferentially kill vegetative cells relative to endospores. Holt and Krieg (1994) found that heating a sample for 10 minutes at $80^{\circ} \mathrm{C}$ would kill vegetative cells but "not harm" endospores. Ethanol at 50-70\% will kill vegetative cells after contact for several minutes but is ineffective against endospores (Barkley and Richardson 1994). Although the ethanol method would have disadvantages for our future needs because it would complicate the dilution process, we considered it a useful tool to confirm the efficacy of the heating approach. The basic strategy proposed was to

1. Plate an aliquot of a sample following known dilution and count colonies of both vegetative cells and endospores to obtain total counts (TC).

2. Heat the remainder of the diluted sample after extraction from the soil but prior to a second plating to kill the vegetative cells, leaving only the endospores $(\mathrm{E})$.

3. Derive vegetative cells (VC) from the difference of TC minus E.

To confirm that heating killed the vegetative cells, we compared the growth of samples that were heated to samples that received an ethanol-wash treatment. Because both treatments are effective at killing vegetative cells, the results from these two independent approaches should be similar. 


\section{Materials and methods}

\section{Evaluations of heat treatment}

We used soils that we inoculated with BG endospores or mixtures of both vegetative cells and endospore BG. We placed $10 \mathrm{~g}$ of soil into bottles containing $95 \mathrm{~mL}$ of sterile water. The soil was the same as used in objective 1 (Table 1). The contents were then mixed on a reciprocating shaker for 5 minutes, removed from the shaker, and mixed by hand through a full $90^{\circ}$ arc. Following mixing, 10 $\mathrm{mL}$ was placed into dilution bottles containing $90 \mathrm{~mL}$ of sterile deionized (DI) water. The same mixing and diluting procedure was performed several more times to yield serial dilutions of the endospores and mixed samples.

From select dilutions of each sample, $100-\mu \mathrm{L}$ aliquots were immediately plated onto $1.0 \times$ TSA. For the heat treatment, we first pipetted approximately 2 $\mathrm{mL}$ of soil-bacteria-water suspension into a labeled, sterile sample vial. The vials were placed into plastic Ziploc ${ }^{\mathrm{TM}}$ bags, and excess air was pressed from the bags, which were then sealed, weighted, and submerged into an $80^{\circ} \mathrm{C}$ constanttemperature water bath for 5, 10, and 15 minutes. It is important to remove excess air so that the heated water is not held away from the vial by entrapped air. The bagged vials were then removed from the heating bath, and the samples were quickly cooled to room temperature by submergence in a cool-water bath. A $100-\mu \mathrm{L}$ aliquot of each suspension was then plated in triplicate onto 1.0× TSA. Following plating, all plates were incubated in the dark at $28^{\circ} \mathrm{C}$.

\section{Comparison of heating to ethanol wash}

We inoculated $10 \mathrm{~g}$ of soil with a vegetative-endospore BG inoculant. The soil was immediately extracted, and the extracts were then diluted as described above for the heat treatments. After all dilutions were prepared, $2 \mathrm{~mL}$ from each dilution was placed into small vials that were then placed in a hot-water bath as described above. Using paired samples, a second 10-mL aliquot from each dilution was also placed in a sterile $40-\mathrm{mL}$ vial. Rather than treating these vials in an $80^{\circ} \mathrm{C}$ hot-water bath for 10 minutes, an aliquot of ethanol was added to the vial to make a $70 \%$ (v) solution. The vials were treated with ethanol for 5,10 , and 15 minutes and then plated as described earlier. We tested two approaches to plating. In the first approach, we plated as usual, placing the agar plate lid back on the plate immediately after plating. In the second approach, we left the lid off after plating until the ethanol evaporated. 


\section{Results and discussion}

Comparison of heat vs. ethanol treatment to selectively kill vegetative cells

All samples had substantial numbers of both endospores and vegetative cell populations prior to treatment. A one-way ANOVA showed that there were no effects on endospore survival among heating at $80^{\circ} \mathrm{C}$ for 10 minutes and either ethanol treatment. As noted earlier, heating kills vegetative cells and, given sufficient temperatures and time, can also kill endospores, while ethanol is known to kill only vegetative cells and not endospores. Our data showed that heating at $80^{\circ} \mathrm{C}$ for 10 minutes did not significantly reduce the number of viable endospores relative to ethanol treatments. Heating also avoids issues with dilution caused by adding ethanol to dilutions and potential problems from residual ethanol remaining on plating media surfaces. We concluded that heating at $80^{\circ} \mathrm{C}$ for 10 minutes was efficient in killing vegetative BG cells while having a minimal impact on endospore BG (Fig. 2).

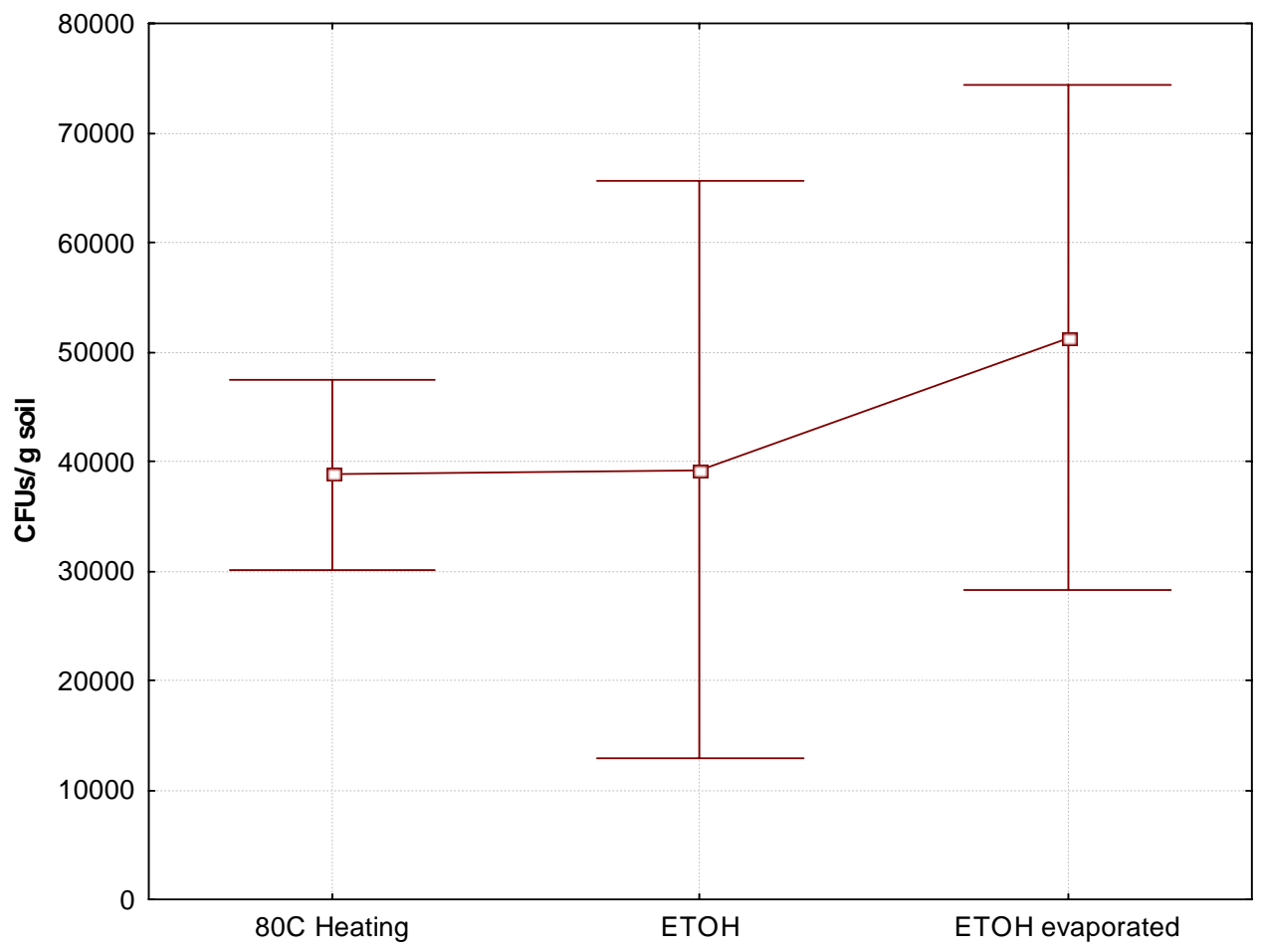

Figure 2. Effect of different treatments used to kill vegetative cells on endospore survival. 


\section{OBJECTIVE 3: REPRODUCING ENDOSPORE AND VEGETATIVE CELL CULTURES}

For endospore generation a series of processes need to occur in sequence. After initiation these processes can continue to some degree simultaneously, although the net processes of the system proceed in the sequence: endospore, germination, logarithmic growth, stationary growth, and sporulation.

1. During endospore germination the endospores leave their dormant state to become vegetative bacteria. Prior to active growth, vegetative cells may remain in a lag phase for a period of time until they become acclimated to the surrounding conditions.

2. Following acclimation, logarithmic growth can occur if sufficient carbon and inorganic nutrients are available. This is a stage when vegetative cells grow at a maximal rate.

3. Exponential growth then slows to a stationary phase, which is characterized by low rates of cell division because of a reduction in available substrates, production and accumulation of metabolic byproducts, or an overall decrease in conditions favorable for growth.

4. For endospore-forming bacteria such as BG, cell death, cell sporulation, or both can ensue as vegetative cells alter their cell-division process to form endospores as a survival mechanism.

Objective 3 was to evaluate and establish methods for the reproduction of BG endospores and vegetative cells from a single culture. Nephelo flasks and a spectrophotometer were used to develop a reproducible technique for determining the extent of spore germination and the rate of cell growth. Turbidity measurements were used to monitor growth in the flasks containing media with different carbon sources. We then selected one carbon source that produced a useful growth curve and conducted a second incubation. During the second incubation we selected sample times associated with identifiable points on the turbidity-derived growth curve, and, at these times, we obtained plate counts and made visual inspections of the cells using microscopy. In this way we could correlate the growth phase with differing ratios of vegetative cells and endospores. 


\section{Materials and methods}

\section{Determining number of endospores per mass of endospore powder}

Measuring treatment effects on endospore die-off uses BG survival as a dependent variable. To best discern treatment effects, we needed to be able to inoculate each experimental unit equally. Because of the small size and mass of endospores, we determined that adding a consistent number of endospores to a soil or growth medium would require adding the endospores as an aliquot of a well-mixed endospore-water suspension. To make this suspension, we estimated the number of endospores per mass of dry endospore powder. This was done by conducting serial dilutions and plating the dry endospore powder. Our resulting data indicated that $1 \mathrm{~g}$ of BG endospore powder contained approximately $10^{11}$ endospores.

\section{Turbidity measurements for relative growth}

Turbidity measurements were made using a Hach spectrophotometer modified to accept a Nephelo flask. We used a wavelength of $450 \mathrm{~nm}$ and a 19-mm path length. Other systems would work equally well since these are relative measurements taken from the same flask over a time period. Koch (1994) states that the important point concerning turbidometric techniques is that there is no set procedure. Turbidity measurements (formazin turbidity units) were plotted against time to yield growth curves.

\section{Initial Nephelo flask incubations: Obtaining a representative growth curve}

Replicate Nephelo flasks were inoculated with a suspension of BG endospores in sterile water. A variety of candidate carbon sources were tested, including soil extract broth, $0.01 \times$ Tryptic soy broth (TSB), $0.1 \times \mathrm{TSB}, 1.0 \times \mathrm{TSB}$, and $1.0 \times$ TSB with dextrose added. Flasks were then incubated at $28^{\circ} \mathrm{C}$ and 122 revolutions per minute on an orbital shaker. The first turbidity measurements were taken immediately after the flasks were inoculated with the endospore suspension; additional measurements were taken over an eight-day period.

After establishing growth curves using the turbidity measurements, we selected $0.1 \times$ TSB as the carbon source yielding the most robust profile (Fig. 3) and used aliquots from the $0.1 \times$ TSB flasks to prepare an inoculating suspension for a second incubation. Cell morphology was confirmed by microscopy using the Schaeffer-Fulton method for endospore staining (Appendix B). Microscopic examination revealed that the BG suspension (following incubation) was composed primarily of endospores. 


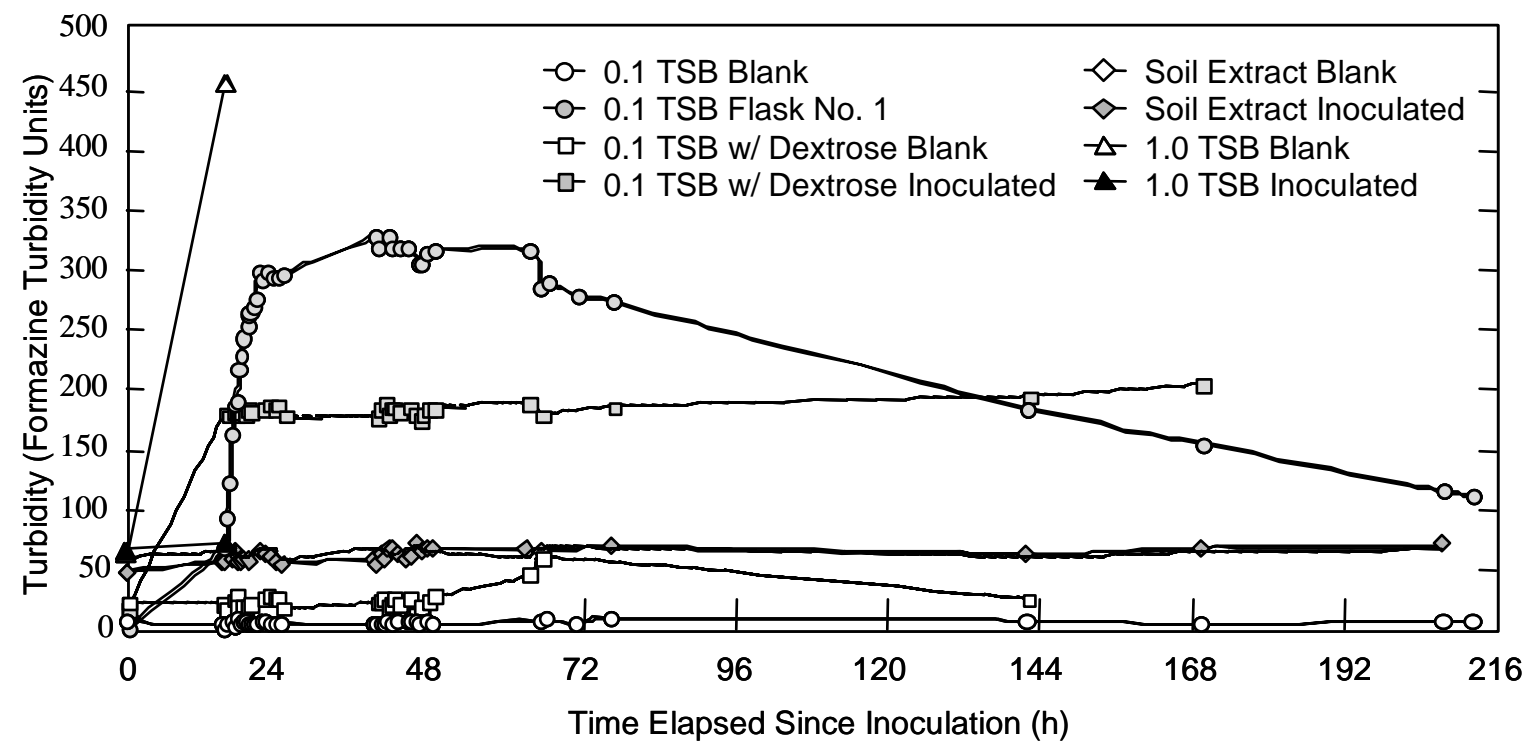

Figure 3. Turbidity-derived growth curves of BG grown from endospores using a range of carbon sources for BG growth.

Second Nephelo flask incubations: Correlating growth-curve phases with endospore:vegetative cell ratios

Although turbidity measurements allow for relatively easy monitoring of cell growth and are a standard technique for monitoring biomass efficiently, turbidity measurements do not indicate if or when sporulation of the newly produced vegetative cells has occurred. As growing cells deplete the media carbon, the cells can either die or sporulate, with either process affecting turbidity. To identify the approximate ratio of endospores to vegetative cells of BG growing in a known substrate, we conducted a second incubation.

At the end of the first incubation, a 10.0-mL aliquot of the BG suspension was taken from the $0.1 \times$ TSB flask and placed into a dilution bottle containing 90 $\mathrm{mL}$ of sterile deionized water. The bottle was thoroughly shaken and stored at $4^{\circ} \mathrm{C}$ for use as the inoculating endospore suspension in this second incubation.

Using three replications, $10 \mathrm{~mL}$ of the endospore suspension were added to Nephelo flasks containing $90 \mathrm{~mL}$ of $0.1 \times$ TSB. A control flask containing $10 \mathrm{~mL}$ of sterile water added to $90 \mathrm{~mL}$ of $0.1 \mathrm{TSB}$ was prepared as a blank. Flasks were then incubated at $28^{\circ} \mathrm{C}$ and $122 \mathrm{rpm}$ on an orbital shaker, and the turbidity of the system was monitored as before. In addition, aliquots were taken at alternate turbidity readings for colony counting and microscopy. Details of the procedure of each sampling episode are presented in Appendix C. The endospore:vegetative 
cell ratio was determined using the differentiation method described in objective 3.

Our purpose in selecting sampling times for each of the $0.1 \times$ TSB flasks was to obtain five points to best approximate the growth curve. These points were

- End of lag-phase/beginning of log phase,

- Midway through log phase,

- End of log phase,

- Sporulation/beginning of death phase, and

- Asymptotic area of death phase.

We used these data to develop a relationship between turbidity readings and population sizes as determined by plate counts. Data from the plate counts also provided information on the ratio of endospores to vegetative cells in the flasks at each sampling time. These data were then used to estimate when vegetative growth had reached logarithmic phase, when sporulation had begun, and when sporulation was essentially complete.

\section{Results and discussion}

\section{Growth curves with different carbon sources}

Growth curves for BG and expressed as turbidity units using soil extract broth, $0.01 \times$ TSB, $0.1 \times$ TSB, $0.1 \times$ TSB with dextrose added, and $1.0 \times$ TSB are shown in Figure 4. Full-strength TSB yielded the fastest growth rate, determined by turbidity measurements, but we selected $0.1 \times$ TSB as the growth medium because it provided ample growth with the clearest delineation of growth phases.

\section{Correlation between turbidity measurements and plate counts}

Although we observed a strong relationship between formazin turbidity units measured at $450 \mathrm{~nm}$ and a 19-mm path length and plate counts using 1.0× TSA as the plating medium, the relationship was clearly not linear (Fig. 5). Using turbidity measurements is common practice for monitoring bacterial growth in solutions, and the correlation between turbidity and plate counts is usually high (Koch 1994). Most of this work has been done to relate actively growing cells in suspension to plate counts (Koch 1994). There is little information on using turbidity measurements for growth that starts as an endospore suspension, germinates and grows vegetatively, and then resporulates during the death phase. For suspensions containing significant percentages of endospores, the difference in size and shape of endospores relative to vegetative cells may impact turbidity readings differentially. The relationship between turbidity measurements at 450 


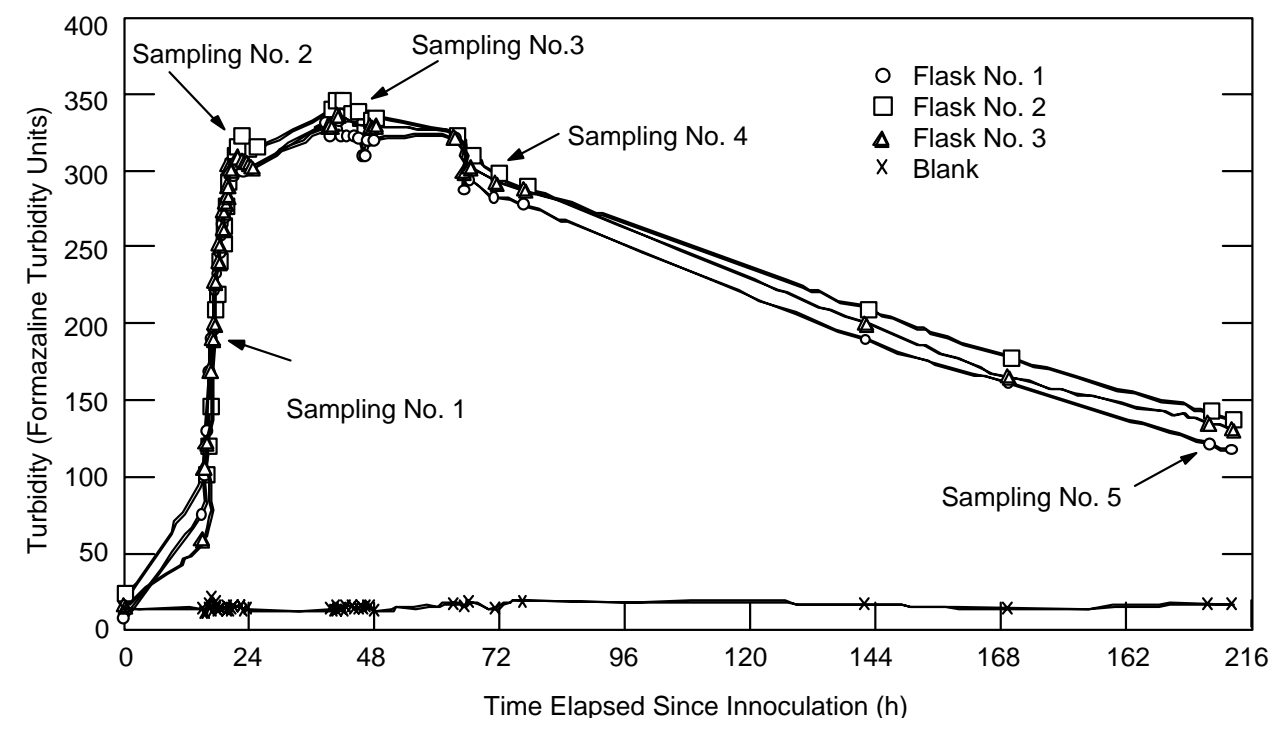

Figure 4. Turbidity-measured growth curves (in formazin turbidity units) of BG grown from endospores in 0.1× TSB. Aliquots were taken at selected sampling times, samples were stained for microscopy, and the endospore:vegetative cell ratio was characterized using differentiation methods developed in objective 3.

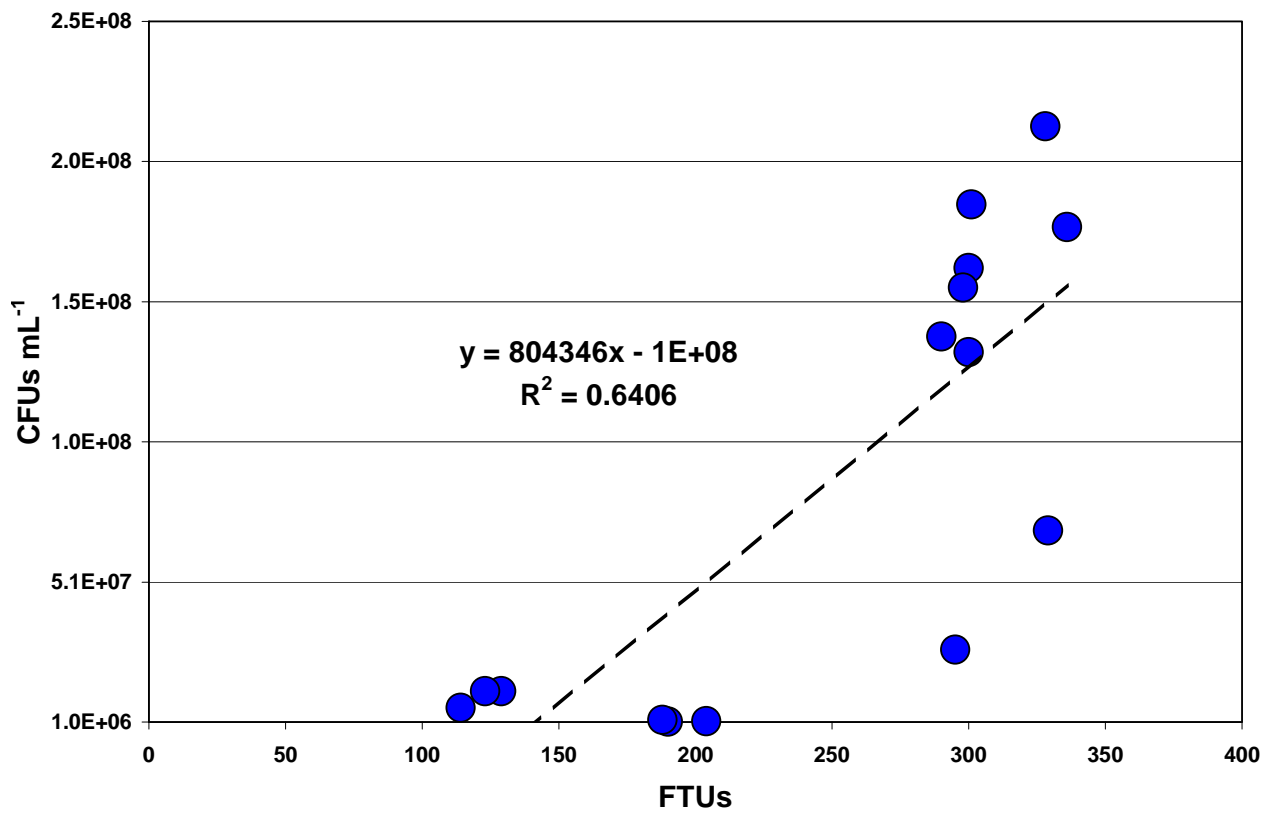

Figure 5. Relationship between formazin turbidity units obtained from Nephelo flasks and cell density obtained from plate counts. 
$\mathrm{nm}$ and plate counts showed a divergence from linearity at both ends of the growth curve, periods when endospores accounted for a significant portion of the total cell count (Fig. 5).

However, using turbidity measurements is a useful monitoring tool for estimating the stages of BG growth. As turbidity plateaued, vegetative cell numbers decreased, endospore formation occurred, and, after an initial increase concurrent with vegetative cell die-off and turbidity decreasing, the endospore count remained constant during the death phase. This was seen for all replications (Fig. 6). Maximum endospore production occurred immediately following maximum turbidity.

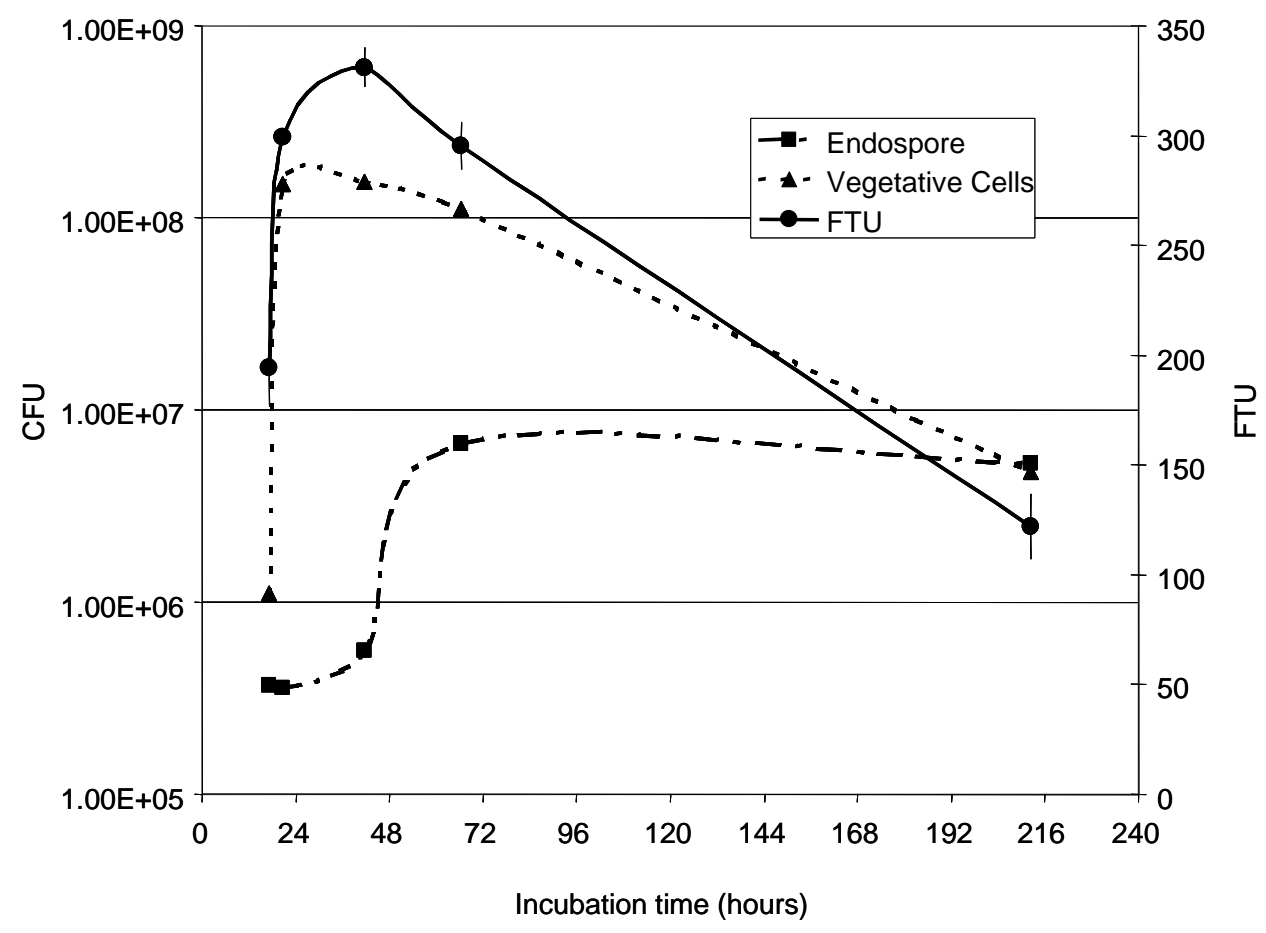

Figure 6. Formazin turbidity units (FTUs) and numbers of colony-forming units (CFUs) for vegetative cells and endospores at each change in BG growth cycle (0-18 hours - Germination; 20-24 hours - log phase; 24-60 hours - stationary phase; 60-216 hours - sporulation). Data are means of three replications. 
Correlation between turbidity measurements and germination, growth, and sporulation

Data in Figure 6 show that, under the conditions of our incubations, spore germination occurred within 18 hours. Vegetative cells were in logarithmic growth from approximately 20 to 24 hours. By 60 hours, logarithmic growth was completed, and the suspension entered a stationary growth phase. By 80 hours, the sporulation process had begun. Quantification of vegetative cell and spore colony-forming units (CFUs) at each change in the growth cycle confirmed the results obtained with the turbidity measurements (Fig. 5). These results were then further validated by microscopic examination. These data were required to effectively reproduce suspensions comprised almost entirely of vegetative cells and endospores. 


\section{OBJECTIVE 4: RECOVERY OF BACILLUS FROM SOIL}

Objective 4 was to determine how well endospores could be recovered after inoculation onto a soil and after increasing incubation periods in a soil. Representative recovery of cells from soil immediately following soil inoculation with a known volume and strength of inoculant is necessary to confirm that the recovery is representative of the cells added.

\section{Materials and methods}

Inoculant preparation

From the initial growth-rate study conducted in objective $3,10 \mathrm{~mL}$ of the incubation flask solution from each of two flasks was transferred into separate sterile dilution bottles containing $90 \mathrm{~mL}$ of deionized water. The solutions from these two dilution bottles were combined in a larger sterile vessel, and approximately $90 \mathrm{~mL}$ of sterile DI water was added to make the inoculant.

To determine the number of CFUs per milliliter of this inoculant, $10 \mathrm{~mL}$ was removed and serially diluted to $10^{-10}$. Three replicates of each dilution were plated and the colonies were counted. The cell density in the inoculant was determined to be $2.6 \times 10^{6} \mathrm{CFU} / \mathrm{mL}$.

\section{Experimental setup and procedure}

Two strengths of inoculant were used on the soils: the original undiluted inoculant described above and the first tenfold dilution of that solution. Two replicates of each inoculant strength were used, resulting in four sample vials. Each vial contained $10 \mathrm{~g}$ of the air-dried Alaskan soil. As a control, $10 \mathrm{~g}$ of the same soil was inoculated with sterile DI water.

For each inoculant level we used the following procedure:

1. Ten grams of air-dried soil was placed into each of five sterile dilution bottles.

2. Two mL of inoculant or sterile deionized water was added and mixed well with a sterile spatula.

3. The dilution bottles were incubated for 10 minutes.

4. Ninety-five milliliters of sterile deionized water and six glass beads were added to each bottle. The bottles were placed on a reciprocating shaker at 
122 rpm for 5 minutes, followed by mixing 20 times by hand. A 0.1-mL aliquot of each bottle was plated on 1.0× TSA.

5. Ten milliliters of each of the dilutions from step 4 were transferred into another dilution bottle containing $90 \mathrm{~mL}$ of sterile deionized water, and the procedure was repeated to obtain a dilution series culminating at $10^{-4}$.

For each of the two soil samples inoculated with the highest cell densities, we plated the $-2,-3$, and -4 dilutions, using three replicates for each sample dilution. For each of the two soil samples inoculated with a ten-fold dilution of the initial inoculant, we plated the $-1,-2$, and -3 dilutions using three replicates of each sample dilution. For the single soil sample inoculated with sterile DI water, we plated the $-1,-2,-3$, and -4 dilutions using three replicates of each dilution. All plates were incubated at $25^{\circ} \mathrm{C}$ in the dark and counted after three days.

\section{Results and discussion}

For each inoculant level the number of BG colonies that grew on the agar was generally 10-15\% less than predicted from the inoculant dose (Fig. 7). This may represent initial and unpreventable die-off of the added BG in the soil, inefficiencies inherent in extracting viable cells from soil, or errors in counting spore numbers due to spore aggregation. Recovery of either microorganisms or

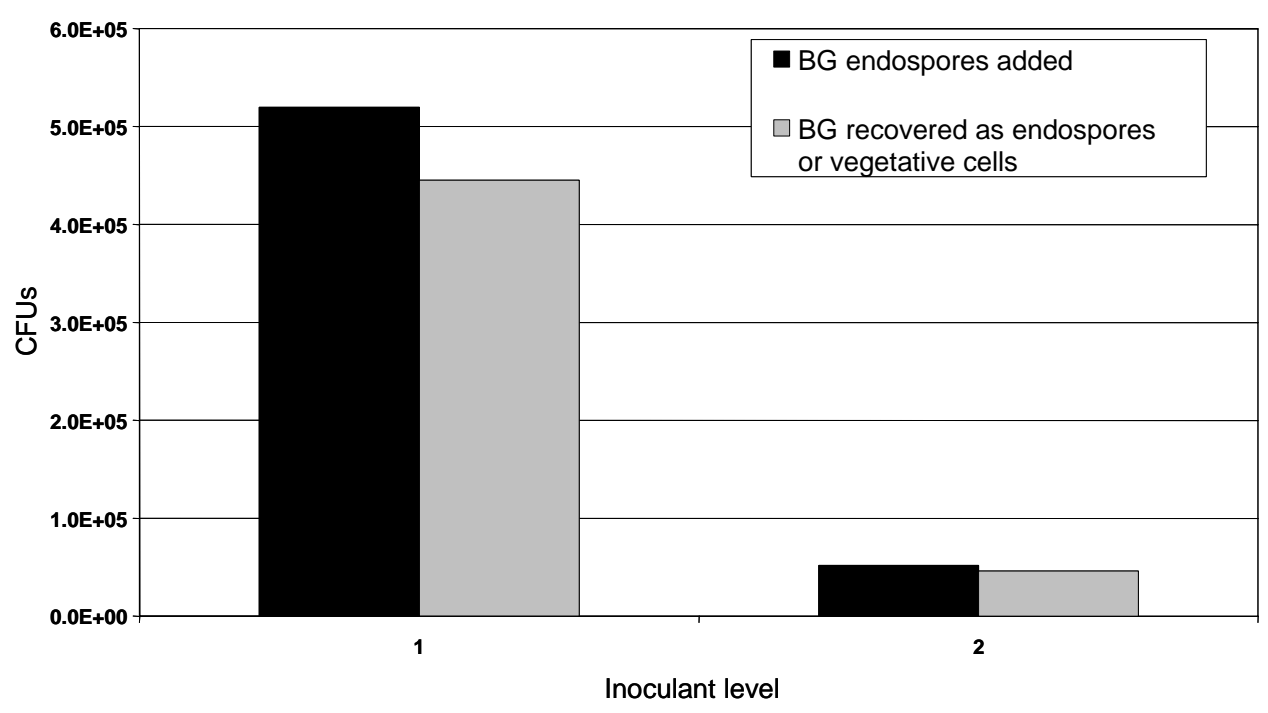

Figure 7. Recovery of viable BG from soil following endospore addition and mixing at two inoculant levels. 
chemicals from soil, including recovery nearly immediately following application, is generally not $100 \%$. Reasons for this include sorption, shock and subsequent death of the added microorganism, incomplete extraction efficiency, and analytical error, although for endospores, cell death is unlikely. This effect is well documented for organic and inorganic chemicals added to soil but less well characterized for microorganisms.

For chemicals an initial extraction and chemical analysis is often done to measure extraction efficiency and test for interferences in the analytical method. Less research has been done to evaluate the efficiency of extracting recently added microorganisms from soil, with the exception of the fate of genetically engineered microorganisms (GEM) (Angle et al. 1994, Soda et al. 1998). Soda et al. (1998) demonstrated that initial die-off can be as much as four orders of magnitude within a seven-day period. 


\section{DISCUSSION AND SUMMARY}

\section{Impediment to decontaminating complex surfaces such as soils}

\section{Consequence management for rough surfaces}

A goal for consequence management following a Bacillus anthracis release will be to reduce endospore densities to acceptable levels in areas where human contact is possible. Recently the difficulties encountered in effectively treating sub-gram quantities of endospores dispersed within structures by routine office activities have been dramatically demonstrated (EPA 2002). There are no standard protocols to use for killing endospores dispersed in structures. Although complex, the surfaces in structures are undoubtedly less complex than soil. Research conducted to evaluate sterilization protocols for medical tools has shown that the decontamination of more intricate surfaces, such as those containing micro fissures or those with large but inaccessible surfaces where endospores can be deposited, is not 100\% effective (Bloomfield and Uso 1985, Klapes and Vesley 1990, Blakistone et al. 1999, Penna et al. 1999). These findings highlight the challenges in killing endospores in complex matrices such as in a soil or on a rough surface in a structure.

\section{Persistence of Bacillus in soils, a complex system}

Endospore formation is a survival strategy for bacteria. Bacillus, an endospore-forming genus, is common in soil, suggesting that a significant number of released Bacillus endospores could survive in any given soil. Using airdried soil to preserve isolates has been an accepted method for many years (Heckly 1978). Studies have shown that Bacillus sp. endospores released in the air and subsequently deposited on soils have persisted from two years to longer than 40 years (Mierzejewski and Bartoszcze 1991, Dragun and Jenny 1995, Smith and Barry 1998). In the largest known aerial release of anthrax endospores, the Sverdlovsk incident in Russia in April 1979, 68 people died after anthrax powder escaped the production facility (Wampler and Blanton 2001). Some of these deaths were delayed, suggesting that subsequent outbreaks of anthrax followed the initial release, although it is difficult to confirm that the later fatalities were directly attributable to endospores in soil being re-aerosolized.

\section{Decontaminating large areas}

There are no well-established methods for treating areas of soil or dust-laden surfaces that are contaminated with endospores. Methods to reduce levels of 
Bacillus anthracis released onto U.S. soils or urban areas have been less thoroughly investigated than decontamination methods for hard surfaces. There are documented reports showing limitations to treating endospores released onto soils (Lindeque and Turnbull 1994, Dragun and Jenny 1995). In some cases, endospore-contaminated areas were quarantined and eventually treated with a strong sterilant (Mierzejewski and Bartoszcze 1991, Nicholson and Law 1999, Small et al. 2001).

In addition to limited guidance and difficulties in confirming success in decontaminating soils, there are also logistic difficulties in treating large areas with strong oxidants. Transporting large volumes of decontamination solution to a site and mixing it into soil is a significant task. At Gruinard Island, where widespread Bacillus anthracis endospore contamination was present, thousands of gallons of formaldehyde mixed with seawater were sprayed and allowed to soak into the upper soil horizons to treat the soils (Mierzejewski and Bartoszcze 1991, Small et al. 2001). Some of the topsoil was also removed in sealed containers. Sheep were then allowed to graze the island. The survival of the sheep illustrated success. There is little information, however, on quantifying pre- and post-treatment endospore densities.

\section{Alternative strategy for decontaminating soils}

An alternative to the aggressive application of a strong chemical would be to enhance the natural die-off of nonindigenous bacteria added to soil. In theory, this can be accomplished by altering soil conditions to favor the indigenous microorganisms. We are increasing our ability to understand how large-scale operations can influence a soil's microbiology (Reynolds and Wolf 1999, Ringelberg et al. 1999, Reynolds et al. 2001), and similar techniques could be applied to soils bio-contaminated with nonindigenous endospores. Merely favoring growth of indigenous microorganisms would not, in itself, kill nonindigenous endospores. Killing endospores on hard surfaces or in a soil is a difficult task (Mierzejewski and Bartoszcze 1991, Smith and Barry 1998, Small et al. 2001). However, killing vegetative cells is relatively easy. We may be able to beneficially exploit this difference.

Understanding the fate of nonindigenous bacteria added to soil requires that we understand their growth and death cycles in the soil. To enhance the natural die-off of nonindigenous endospores, we must understand the growth cycles of nonindigenous bacteria relative to those of the indigenous bacteria. The fate of introduced, nonindigenous endospores is governed by their germination, subsequent vegetative-cell growth, die-off, and/or resporulation, as well as the conditions favoring these processes. In addition, the fate of an introduced 
organism is intricately tied to the growth and metabolism of the native bacteria. Because indigenous and nonindigenous bacteria are competing for resources, understanding their growth and growth stages is fundamental to enhancing the natural attenuation of nonindigenous endospores in soils. Characterizing conditions that influence these processes would improve our ability to modify or predict endospore fate not only in soils, but also on rough, dusty surfaces in buildings. BG is a useful model organism for these studies, and its use would allow these more mechanistic results to be related to results found in earlier studies using BG.

\section{Using BG as a model organism}

$B G$ as surrogate in non-soil and soil systems

BG is a frequently used surrogate for testing the efficacy of decontamination agents in relatively clean systems, such as hard surfaces and structures (Klapes and Vesley 1990, Blakistone et al. 1999). As surfaces become more complex, penetration of a sterilant becomes more problematic and efficacy decreases (Penna et al. 1999, Buttner et al. 2001). Enumeration and identification techniques for soil bacteria that rely on culturing techniques are subject to bias because of the inability of known artificial media to accurately mimic a soil system. These limitations should be recognized in interpreting the results from investigations using culture-based techniques for soil bacteria, but they do not invalidate studies for monitoring the fate and persistence of nonindigenous bacteria in soils.

Although BG may be common in select soils, we have not observed it in any of the soils used in our laboratory. However, for BG fate studies, lack of presence of BG should be confirmed before a specific soil is selected for study. Using Bacillus thuringiensis (Bt) or BG as a model organism to investigate the persistence of endospores in soils has been previously reported (HinojosaRebollar et al. 1995, Kuske et al. 1998, Smith and Barry 1998), but using BG to follow the vegetation, resporulation, persistence, and fate of nonindigenous bacteria released onto soils has not. We have shown that BG is a suitable surrogate for investigating endospore fate in soil, although we stress the need to confirm the status of BG as a possible native inhabitant in the soil being investigated.

\section{BG growth characteristics}

BG is not a pathogen, it is readily grown to high cell densities under laboratory conditions, and it readily forms endospores as the growth medium is depleted. When plated on TSA, BG colonies are distinctively orange, making 
their visual recognition among indigenous bacteria on TSA plates relatively easy. These characteristics make it possible to regenerate BG stocks for continued studies. Because of its distinctive color when grown on TSA, using BG in “clean” systems has advantages.

BG can be readily grown in most laboratories and harvested at appropriate stages in the growth cycle to provide inoculant mixtures of various endospore: vegetative cell ratios. A $0.1 \times$ TSB growth medium is adequate for regenerating BG stocks. Although greater growth could be obtained using 1.0× TSB, greater growth rates presented logistical challenges for the timing of the harvest. Developing known endospore:vegetative cell mixtures requires that both growth curves and accompanying relationships between growth curves and endospore: vegetative cell ratios be developed for a laboratory's specific growth conditions. We have developed growth curves for our laboratory and confirmed that turbidity measurements can be related to vegetative cell density during the logarithmic growth phase. Microscopic evaluations confirmed that relatively few endospores were present during the logarithmic growth stage. The protocols described in this report can serve as a basis upon which a laboratory-specific procedure can be developed.

\section{Differentiating $B G$ from soil bacteria and vegetative $B G$ from endospore $B G$}

Using color we were able to differentiate BG from the indigenous bacteria in the soil we used. Visual identifications were confirmed by FAME analysis. To differentiate endospores from vegetative cells, heating the serial dilutions to $80^{\circ} \mathrm{C}$ for 10 minutes prior to plating proved effective in killing vegetative cells. Depending on specific laboratory equipment, exact protocols may need to be varied to ensure that the diluted suspensions are heated uniformly because the duration and degree of heating can impact both vegetative cell and endospore die-off. Consistency in protocols is important. At present, options are limited for differentiating between live and dead endospores. Growth on a medium known to support BG is required, and positive controls need to be included. Techniques to differentiate live from dead endospores would fill a much-needed research capability gap and improve our mechanistic understanding of soil conditions and processes and how they influence endospore survival and fate in soil.

\section{Inherent BG die-off in soil and limitations to its use as a model organism}

There are precautions that need to be recognized when using BG as a model organism in soils. At all inoculant levels tested, BG recovery was $85-90 \%$ of that applied. This may represent initial and unpreventable die-off of the added BG in the soil, it could be explained by inefficiencies inherent in extracting viable cells 
from soil, or it could be explained by error in the enumeration methodology due to spore aggregation. Recovery of either microorganisms or chemicals from soil, including recovery nearly immediately following application, is generally not $100 \%$. This effect is well documented for organic and inorganic chemicals added to soil but less well characterized for microorganisms. Microorganisms added to soil can either die or survive, and, in time, those that survive can multiply. In studying the fate of microorganisms added to soil, the goal can be short-term dieoff of enteric pathogens, such as in wastewater treatment by overland flow. Conversely, for agricultural seed inoculation or bioaugmentation for environmental remediation, long-term survival is desired. The majority of these studies have been done with non-endospore-forming bacteria, and research has shown that survival of vegetative bacteria added to soil varies widely (Dileep-Kumar and Dube 1992, Angle et al. 1994). For viable vegetative cells, initial die-off can be as much as four orders of magnitude within seven days (Angle et al. 1994, Soda et al. 1998).

There is little research addressing mechanisms governing the fate of endospores added to soil. It is well documented that endospores are resistant to many harsh environments, can remain viable in soil for extended periods, and are common in soil. Recovery of added endospores appears to represent a region somewhere between recalcitrant chemicals and vegetative cells. Our data show that, with appropriate attention to potential limitations inherent in cultural approaches for bacteria in oligotrophic environments, BG can be used as a model organism for understanding the mechanisms that govern Bacillus fate in soil, including changes between vegetative and endospore forms. 


\section{REFERENCES}

Adrian, N.R., and C.M. Arnett (2001) Isolation of an RDX-degrading acetogenic bacterium from a mixed culture that degrades TNT, RDX, and HMX under anaerobic Conditions. In Proceedings of 22nd Army Science Conference, Baltimore, Maryland, p. 418-423.

Angle, J.S., M.A. Levin, J.V. Gagliardi, M.S. McIntosh, and J.G. Glew (1994) Pseudomonas aureofaciens in soil: Survival and recovery efficiency. Microbial Reviews, 2: 247-254.

Atlas, R.M. (1998) Biological weapons pose challenge for microbiology community. American Society for Microbiology News, 64: 372-373.

Barkley, W.E., and J.N. Richardson (1994) Laboratory safety. In Methods for General and Molecular Bacteriology (P. Gerhardt, R.G.E. Murray, W.A. Wood, and N.R. Krieg, ed.). Washington, D.C.: American Society for Microbiology, p. 715-734.

Blakistone, B., R. Chuyate, D. Kautter Jr., J. Charbonneau, and K. Suit (1999) Efficacy of oxonia active against selected spore formers. Journal of Food Protection, 62(3): 262-267.

Bloomfield, S.F., and E.E. Uso (1985) The antibacterial properties of sodium hypochlorite and sodium dichloroisocyanurate as hospital disinfectants. Journal of Hospital Infections, 6(1): 20-30.

Busbee, W.L. (1998) Keynote address. Worldwide Chemical Conference and Exhibition XVI, Fort McClellan, Alabama, 23-25 June 1998.

Buttner, M.P., P. Cruz-Perez, and L.D. Stetzenbach (2001) Enhanced detection of surface-associated bacteria in indoor environments by quantitative PCR. Applied Environmental Microbiology, 67(6): 2564-2570.

Colwell, R.R., and D.J. Grimes (2000) Semantics and strategies. In Nonculturable Microorganisms in the Environment (R.R. Colwell and D.J. Grimes, ed.). Washington, D.C.: ASM Press, p. 1-6.

Dileep-Kumar, B.S., and H.C. Dube (1992) Seed bacterization with a fluorescent pseudomonad for enhanced plant growth, yield and disease control. Soil Biology and Biochemistry, 24: 539-542.

Dragun, D.C., and R.P. Jenny (1995) The ecology of anthrax spores: Tough but not invincible. Canadian Veterinary Journal, 36(5): 295-301.

EPA (2002) EPA's role in responding to anthrax contamination. (http://www. epa.gov/epahome/hi-anthrax.htm), 29 March 2002. 
Gardner, D.W.M., and G. Shama (1998) The kinetics of Bacillus subtilis spore inactivation on filter paper by u.v. light and u.v. light in combination with hydrogen peroxide. Journal of Applied Microbiology, 84(4): 633-641.

Heckly, R.J. (1978) Preservation of microorganisms. Advances in Applied Microbiology, 24: 1-53.

Hinojosa-Rebollar, R.E. (1995) Biological flow tracers: Growth and survival of Bacillus subtilis 65-8 under environmental stress. Reviews in Latin American Microbiology, 37(1): 43-53.

Holt, J.G., and N.R. Krieg (1994) Enrichment and isolation. In Methods for General and Molecular Bacteriology (P. Gerhardt, R.G.E. Murray, W.A. Wood, and N.R. Krieg, ed.). Washington, D.C.: American Society for Microbiology, p. 179-215.

Klapes, N.A., and D. Vesley (1990) Vapor-phase hydrogen peroxide as a surface decontaminant and sterilant. Applied and Environmental Microbiology, 56(2): 503-506.

Koch, A.L. (1994) Growth measurement. In Methods for General and Molecular Bacteriology (P. Gerhardt, R.G.E. Murray, W.A. Wood, and N.R. Krieg, ed.). Washington, D.C.: American Society for Microbiology, p. 248-277.

Kuske, C.R., K.L. Banton, D.L. Adorada, P.C. Stark, K.K. Hill, and P.J. Jackson (1998) Small-scale DNA sample preparation method for field PCR detection of microbial cells and spores in soil. Applied and Environmental Microbiology, 64(7): 2463-2472.

Lindeque, P.M., and P.C. Turnbull (1994) Ecology and epidemiology of anthrax in the Etosha National Park, Namibia. Onderstepoort Journal of Veterinary Research, 61(1): 71-83.

Lynch, J. (1998) Assessment of the impact of chemical and biological weapons on joint operations in 2010 (CB2010—The Foss Study). Paper presented at Worldwide Chemical Conference and Exhibition XVI, Fort McClellan, Alabama, 23-25 June 1998.

Menetry, L., and J. Coverstone (1998) CINC assistance update. Paper presented at Worldwide Chemical Conference and Exhibition XVI, Fort McClellan, Alabama, 23-25 June 1998.

Mierzejewski, J., and M. Bartoszcze (1991) Decontamination of soil after bacterial warfare experiments on Gruinard Island. Przegl Epidemiology, 45(3): 197205. 
MIDI, Inc. (1995) Sherlock Microbial Identification System. Newark, Delaware: MIDI, Inc.

Moore, A. (1998) Detecting biological agents. Army Chemical Review, 24-25 January.

Nicholson, W.L., and J.F. Law (1999) Method for purification of bacterial endospores from soils: UV resistance of natural Sonoran desert soil populations of Bacillus spp. with reference to B. subtilis strain 168. Journal of Microbiological Methods, 35(1): 13-21.

Obeta, J.A. (1996) Effect of inactivation by sunlight on the larvicidal activities of mosquitocidal Bacillus thuringiensis H-14 isolates from Nigerian soils. Journal of Communicable Diseases, 28(2): 94-100.

Osterholm, M. (1998) Public health infrastructure testimony. 2 June 1998, Testimony before the Senate Labor, Health and Human Services, Education and Related Agencies Appropriations Subcommittee on the Nation's Public Health Infrastructure Regarding Epidemics and Bioterrorism.

Penna, T.C., C.A. Ferraz, and M.A. Cassola (1999) The presterilization microbial load on used medical devices and the effectiveness of hydrogen peroxide gas plasma against Bacillus subtilis spores. Infectious Control of Hospital Epidemiology, 20(7): 465-472.

Perkins, J.J. (1969). Principles and Methods of Sterilization in Health Sciences. 2nd edition. Springfield, Illinois: C.C. Thomas.

Reynolds, C.M., and D.C. Wolf (1999) Microbial based strategies for assessing rhizosphere-enhanced phytoremediation. In Environmental Technology Advancement Directorate (ETAD) of Environment Canada - Phytoremediation Technical Seminar, 31 May-1 June, Calgary, Alberta, p. 125-135.

Reynolds, C.M., B.A. Koenen, L.B. Perry, K.L Foley, D.B. Ringelberg, and K.J. McCarthy (2001) Phytoremediation in Korea: Evidence for rhizosphereenhanced PAH degradation. In Proceedings of the 6th International Symposium, In-Situ and Onsite Bioreclamation, 4-7 June, San Diego, California. Columbus, Ohio: Battelle Press, 6(5): 9-16.

Ringelberg, D., E. Perkins, L. Hansen, J. Talley, and H. Fredrickson (1999) Relating biodegradation potentials to in-situ microbial community composition. In In-Situ Bioremediation of Petroleum Hydrocarbons and Other Organic Compounds (B.C. Alleman and A. Leeson, ed.). Columbus, Ohio: Battelle Press, 5(3): 545-550. 
Roberts, T.A., and A.D. Hitchins (1969) Resistance of spores. In The Bacterial Spore (G.W. Gould and A. Hurst, ed.). New York: Academic Press, p. 611-656.

Sasser, M. (1990) Identification of bacteria through fatty acid analysis. In Methods in Phytobacteriology (Z. Klement, K. Rudolf, and D. Sands, ed.). Budapest: Akademiai Kiado, p. 199-204.

Sasser, M., and M.D. Wichman (1991) Identification of microorganisms through use of gas chromatography and high-performance liquid chromatography. In Manual of Clinical Microbiology (W.J. Hausler, Jr, K.L. Herrmann, H.D. Isenberg, H.J. Shadomy, ed.). 5th edition. Washington, D.C.: American Society for Microbiology, p. 111-118.

Small, I., J. van der Meer, and R.E. Upshire (2001) Acting on an environmental health disaster: The case of the Aral Sea. Environmental Health Perspectives, June, 109(6): 547-549.

Smalla, K., G. Wieland, A. Buchner, A. Zock, J. Parzy, S. Kaiser, N. Roskot, H. Heuer, and G. Berg (2001) Bulk and rhizosphere soil bacterial communities studied by denaturing gradient gel electrophoresis: Plant-dependent enrichment and seasonal shifts revealed. Applied and Environmental Microbiology, 67(10): 4742-4751.

Smith, R.A., and J.W. Barry (1998) Environmental persistence of Bacillus thuringiensis spores following aerial application. Journal of Invertebrate Pathology, 71(3): 263-267.

Smith, J.E,, T.A. Blazek, and R.L. Root (1998) NBC 2000, New paradigm, new challenges. Army Chemical Review, January, p. 25-39.

Soda, S., H. Watatani, M. Ike, and M. Fujita (1998) Factors affecting the survival of exogenous bacteria in microbial ecosystems: Existence of indigenous bacteria with antagonistic activity. Biocontrol Science, 3(2): 63-72.

Steinmetz, COL., LTC Norton, and A. Mitchell (1998) Military support for response to attacks using weapons of mass destruction. Paper presented at Worldwide Chemical Conference and Exhibition XVI, Fort McClellan, Alabama, 23-25 June.

Torsvik, V., J. Goksoyr, and F.L. Daae (1990) High diversity in DNA in soil bacteria. Applied and Environmental Microbiology, 56: 782-787.

Vinter, V. (1969) Physiology and biochemistry of sporulation. In The Bacterial Spore (G.W. Gould and A. Hurst, ed.). New York: Academic Press, p. 73-124. 
Wampler, R.A., and T.S. Blanton (2001) U.S. intelligence on the deadliest modern outbreak. The September 11th Sourcebooks, National Security Archive Electronic Briefing Book No. 61 (http://www.gwu.edu/ nsarchiv/NSAEBB/ NSAEBB61/), 15 November.

Wooten, R.G. (1998) State of the Chemical Corps. Paper presented at Worldwide Chemical Conference and Exhibition XVI, Fort McClellan, Alabama, 2325 June.

Zuberer, D.A. (1994) Recovery and enumeration of viable bacteria. In Methods of Soil Analysis. Part 2. Microbiological and Biochemical Properties, (R.W. Weaver, Ed.), SSSA Book Ser. 5. Madison, Wisconsin: Soil Science Society of America, p. 119-144. 


\section{APPENDIX A. PROCEDURES FOR MEDIA PREPARATION, SOIL DILUTIONS SERIES, PLATING, INCUBATION, COUNTING, AND CLEANUP}

\section{Media preparation}

The $1.0 \times$ tryptic soy agar (TSA) media:

\begin{tabular}{|l|l|}
\hline \multicolumn{1}{|c|}{ Materials } & \multicolumn{1}{c|}{ Preparation } \\
\hline - $\begin{array}{l}\text { 30.0 g tryptic soy broth (TSB) } \\
\text { (Difco No. 0370-17-3) }\end{array}$ & - Add media to 2000-mL Erlenmeyer flask \\
- 15.0 g granulated agar & containing $1 \mathrm{~L} \mathrm{DI}$ water and mix over heat \\
- $1 \mathrm{~L}$ distilled water & - Autoclave at $121^{\circ} \mathrm{C}$ for $15 \mathrm{~min}$ \\
& - Cool to approximately $45^{\circ} \mathrm{C}$ \\
& - Pour media into petri dishes \\
\hline
\end{tabular}

The 0.1 tryptic soy broth (TSB):

\begin{tabular}{|l|l|}
\hline \multicolumn{1}{|c|}{ Materials } & \multicolumn{1}{c|}{ Preparation } \\
\hline $\begin{array}{l}\text { 3.0 g tryptic soy broth (Difco No. } \\
0370-17-3) \text { (Note: Use } 30.0 \mathrm{~g} \text { for } \\
1.0 \mathrm{TSB} \text { and } 0.3 \mathrm{~g} \text { for } 0.01 \mathrm{TSB} \text { ) } \\
\text { 1 } \mathrm{L} \text { distilled water }\end{array}$ & - $\begin{array}{l}\text { Pour the required volume of medium into } \\
\text { the flasks to be used }\end{array}$ \\
\hline
\end{tabular}

Soil extract:

\begin{tabular}{|c|c|}
\hline Materials & Preparation \\
\hline $\begin{array}{l}\text { - } 1.0 \mathrm{~kg} \text { soil sieved through a No. } 10 \\
\text { sieve } \\
\text { - } 1 \mathrm{~L} \text { distilled water }\end{array}$ & $\begin{array}{l}\text { - } \text { Combine the soil with the water and mix } \\
\text { - } \quad \text { Futoclave at } 121^{\circ} \mathrm{C} \text { for } 30 \text { min } \\
41 \text { filter paper and restore volume to } 1.0 \\
\text { L with distilled water } \\
\text { - } \quad \text { As necessary, add more distilled water to } \\
\text { bring optical density (measured in a } \\
\text { Nephelo flask with a spectrophotometer) } \\
\text { to } 72 \text { FTU or less } \\
\text { - } \text { Autoclave two more times, each time at } \\
121^{\circ} \mathrm{C} \text { for } 30 \text { min }\end{array}$ \\
\hline
\end{tabular}




\section{Soil Dilution and Plating}

\section{Materials}

Dilution bottles (95 $\mathrm{mL}$ and $90 \mathrm{~mL}$ volumes as needed)

Top loading balance

Weighing boats

Shaker table

10-mL disposable glass pipets

Pipet bulb

Alcohol lamp (or gas burner)

100- $\mu$ l Eppendorf pipet

Pipet tips

Glass spreading bars [or disposable hockey sticks (Midwest Scientific No.

LLS-50)]

Glass bowls (2)

Inoculation turntable

Plates w/media

Matches

Preparation of dilution bottles

To allow for volume loss during autoclaving, initial dilution volumes should be measured to 97 and $92 \mathrm{~mL}$ to achieve final volumes of 95 and $90 \mathrm{~mL}$ of distilled water, respectively. For -1 ( $95 \mathrm{~mL}$ ) dilution bottles, add three to five glass beads. For -2 and higher dilutions, use $90-\mathrm{mL}$ bottles. Cap all dilution bottles loosely and autoclave at $121^{\circ} \mathrm{C}$ for 15 minutes.

\section{Plating with glass spreading bars}

1. In autoclave bags, autoclave clean glass spreading bars. Allow to dry. Place in a glass bowl and flame with alcohol. Repeat flaming at least once more. Let cool before using.

2. Weigh out $10 \mathrm{~g}$ of soil to be plated. Place soil in -1 dilution bottle. 
3. Shake dilution bottle on horizontal shaker table for 5 minutes. Remove from shaker.

4. Open -2 bottle and sterilize bottle mouth and cap in flame from alcohol lamp or gas burner.

5. Mix -1 dilution bottle 50 times by hand (full $90^{\circ}$ arc).

6. Pipet $10 \mathrm{~mL}$ from -1 bottle into -2 bottle. Flame and cap -2 bottle. Dispose of 10-mL pipet in waste container.

7. Shake -2 dilution bottle on horizontal shaker table for 5 minutes. Remove from shaker.

8. Mix -2 dilution bottle 50 times by hand. If desired, plate -2 dilution on appropriate media plates.

9. Place pipet tip on $100-\mu L$ Eppendorf pipet.

10. Rinse pipet tip with solution from -2 bottle three times. Dispense $100-\mu \mathrm{L}$ solution onto media plates. Dispose of pipet tip in waste container.

11. Place plate, without lid, on inoculation turntable.

12. Holding sterile spreading bar lightly on surface of media, spin inoculation turntable, making sure to spread suspension evenly. Place used glass spreader bar in unused glass bowl (or other suitable container).

13. Place lids on plates and incubate plates upside down at $25^{\circ} \mathrm{C}$.

14. Open -3 dilution bottle and sterilize bottle mouth and lid in flame from alcohol lamp or gas burner.

15. Mix -2 dilution bottle 50 times by hand.

16. Pipet $10 \mathrm{~mL}$ from -2 bottle into -3 bottle. Cap -2 bottle. Dispose of $10-$ $\mathrm{mL}$ pipet in waste container.

17. Mix -3 dilution bottle 50 times by hand.

18. Plate -3 dilution and continue for -4 and lower dilutions.

Continue in this manner, plating where appropriate to media.

Notes:

Only -1 and -2 dilution bottles get shaken on the shaker table.

Use only sterile pipets or pipet tips. Do not forget to flame the cap and bottle each time it is opened. 


\section{Soil moisture determination}

Determine moisture content of soil by drying a known amount of soil at $105^{\circ} \mathrm{C}$ to a constant weight (approximately $24 \mathrm{~h}$.).

\section{Cleanup}

All glassware and dilution bottles should be autoclaved at $121^{\circ} \mathrm{C}$ for 15 minutes prior to cleaning or disposal. After autoclaving, the glass pipets can be disposed of in a waste-glass container. Used pipet tips and other materials may be disposed of in appropriate waste containers after autoclaving. Rinse the dilution bottles in a sink, making sure to catch any soil waste and glass beads in a fine sieve. Rinse the glass spreading bars and wash the bars and dilution bottles in a dishwasher. Autoclave to reuse the spreading bars.

\section{Reading plates}

- Incubate plates in the dark at $25^{\circ} \mathrm{C}$.

- For bacterial colonies on $0.1 \times$ TSA, read following 3 and 7 days after inoculation.

- Calculate and report values as $\log _{10}$ CFU/g dry soil. 


\section{APPENDIX B: SCHAEFFER-FULTON METHOD FOR ENDOSPORE STAINING}

\section{Materials}

Malachite Green Stain

Malachite Green $\quad 0.5 \mathrm{~g}$

Deionized water $100 \mathrm{~mL}$

Counterstain

Safranin O $\quad 10 \mathrm{~mL}$ as a $2.5 \%(\mathrm{w} / \mathrm{v})$ alcoholic solution in $95 \%$ ethanol

Deionized water $100 \mathrm{~mL}$

\section{Procedure}

1. Place a slide with an air-dried, heat-fixed smear on a slide carrier over a trough. Cut a piece of absorbent paper to fit the slide and saturate the paper with the malachite green stain. Allow to stand for 30 to $60 \mathrm{~s}$ and then carefully heat the underside of the slide by passing a flame under the slide until steam rises WITHOUT BOILING. Keep the preparation moist with stain and steam for 5 minutes, adding stain and heating as needed. Allow the slide to cool and remove the paper. Wash the film with a gentle and indirect stream of de-ionized water until no color appears in the effluent.

2. Flood the smear with the safranin counterstain for 1 minute. Wash with water as above and blot dry.

3. Examine under oil immersion. Endospores appear bright green and vegetative cells appear brownish-red. 


\section{APPENDIX C: PROTOCOL FOR SAMPLING NEPHELO FLASKS}

1. Remove $10.0 \mathrm{~mL}$ from each flask and place in sterile dilution bottle containing $90 \mathrm{~mL}$ of deionized water.

2. Dilute as in Appendix A to -6 .

3. Plate the -3 to -6 dilutions, $0.1 \mathrm{~mL}$ per plate, on $1.0 \times$ TSA plates, with three replicates of each.

4. After plating each dilution, use a sterile pasteur pipet to place $\pm 2 \mathrm{~mL}$ of that dilution into a 2-mL GC vial.

5. After plating dilutions from each flask, place filled GC vials in a small Ziploc bag and then place bag in $80^{\circ} \mathrm{C}$ water for 10 minutes.

6. Plate the "killed" dilutions as in Appendix A.

7. Prepare a microscope slide with solution directly from each flask. Place a drop of liquid from each flask on a slide, air dry, heat fix, and stain with endospore stains as described in Appendix B. 


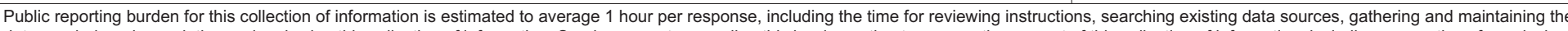

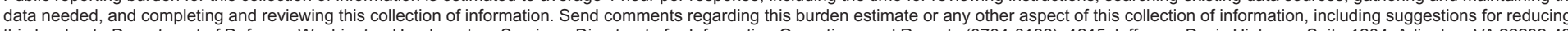

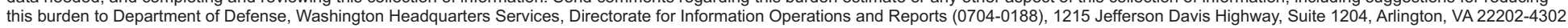

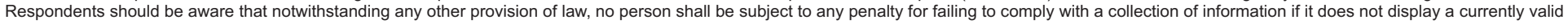
OMB control number. PLEASE DO NOT RETURN YOUR FORM TO THE ABOVE ADDRESS.

\begin{tabular}{|l|l|}
\hline $\begin{array}{l}\text { 1. REPORT DATE }(D D-M M-Y Y) \\
\text { November } 2003\end{array}$ & $\begin{array}{l}\text { 2. REPORT TYPE } \\
\text { Technical Report }\end{array}$ \\
\hline 4. TITLE AND SUBTITLE &
\end{tabular}

\section{TITLE AND SUBTITLE}

Fate of Nonindigenous, Endospore-Forming

Bacteria in Soils

\section{DATES COVERED (From - To)}

5a. CONTRACT NUMBER

5b. GRANT NUMBER

5c. PROGRAM ELEMENT NUMBER

6. AUTHOR(S)

5d. PROJECT NUMBER

Charles M. Reynolds, Karen L. Foley, David B. Ringelberg, and Lawrence B. Perry

5e. TASK NUMBER

5f. WORK UNIT NUMBER

8. PERFORMING ORGANIZATION REPORT

\section{PERFORMING ORGANIZATION NAME(S) AND ADDRESS(ES)}

U.S. Army Engineer Research and Development Center

Cold Regions Research and Engineering Laboratory

72 Lyme Road

ERDC/CRREL TR-03-23

Hanover, NH 03755-1290

9. SPONSORING/MONITORING AGENCY NAME(S) AND ADDRESS(ES)

10. SPONSOR / MONITOR'S ACRONYM(S)

11. SPONSOR / MONITOR'S REPORT NUMBER(S)

\section{DISTRIBUTION / AVAILABILITY STATEMENT}

Approved for public release; distribution is unlimited.

Available from NTIS, Springfield, Virginia 22161.

13. SUPPLEMENTARY NOTES

\section{ABSTRACT}

Persistence of nonindigenous microorganisms released onto soils or into natural environments can have a significant impact on Department of Defense (DoD) operations. An understanding of competition among various microbial communities is necessary to accurately predict the types of microorganisms that will flourish as well as those that will wane under differing environmental scenarios. In the past, soil microbiology was altered with brute-force techniques such as the saturation of a soil with a decontamination agent. An approach that is more feasible for large areas is to alter soil conditions to promote the desired microbial status or to effectively predict their fate in field conditions. Ultimately, the ability to accurately predict the occurrence of a dominant microbial community will be useful both for predicting the fate of pathogens in the environment and for fostering success in the bioremediation of soils and sediments.

Bacillus globigii (BG) was selected to investigate the persistence and fate of nonindigenous bacteria released onto soils. We were able to differentiate BG from indigenous bacteria by combining culturing techniques with lipid-based validation. Enrichment on agar plates produced bright orange $\mathrm{BG}$ colonies that were clearly distinct from native microorganisms. These data suggest that there is either an initial loss in viability or an inability to recover $10-15 \%$ of the BG soon after inoculation onto the soil.

\begin{tabular}{|c|c|c|c|c|c|}
\hline 15. SUBJECT TERMS & $\begin{array}{l}\text { Anthrax } \\
\text { Bacteria }\end{array}$ & & $\begin{array}{l}\text { fense } \\
\text { pores }\end{array}$ & $\begin{array}{l}\text { Persis } \\
\text { Soil }\end{array}$ & \\
\hline 16. SECURITY CLASS & ATION OF: & & 17. LIMITATION OF & 18. NUMBER & 19a. NAME OF RESPONSIBLE PERSON \\
\hline a. REPORT & b. ABSTRACT & c. THIS PAGE & & & 19b. TELEPHONE NUMBER (include area code) \\
\hline $\mathrm{U}$ & $\mathrm{U}$ & $\mathrm{U}$ & $\mathrm{U}$ & 46 & \\
\hline
\end{tabular}

